Journal of Advanced Research in Fluid Mechanics and Thermal Sciences

\title{
Parametric Assessment of The Thermal Performance of Coal-Fired Power Plant
}

\author{
Omar J Khaleel ${ }^{1, *}$, Firas Basim Ismail ${ }^{1}$, Thamir Khalil Ibrahim ${ }^{2, *}$ \\ 1 Power Generation Unit, Institute of Power Engineering (IPE), Universiti Tenaga Nasional (UNITEN), 43000 Kajang, Selangor, Malaysia \\ 2 Department of Mechanical Engineering, College of Engineering, Tikrit University, Tikrit, Iraq
}

ARTICLE INFO ABSTRACT

Article history:

Received 10 June 2021

Received in revised form 22 August 2021

Accepted 25 August 2021

Available online 17 September 2021

\section{Keywords:}

Coal-Fired; Power plant; Exergy; Superheated; Feedwater Heaters

\begin{abstract}
Exergy analysis has been found to be a useful method for improving the conversion efficiency of energy resources, since it helps to identify locations, types and true magnitudes of wastes and losses. The aim of this research is to analyze the effect of the operation conditions on the performance of coal-fired power plants. As well, this study focuses on the effect of different feedwater heaters' numbers that lead to the highest exergy destruction of the coal-fired power plants. For different values of the superheated steam temperature and the pressure, a parametric study was conducted to determine the efficiency of the coal-fired power plant. The results show that, when the pressures and temperature of the superheated steam increases the evaporator temperature will increases too. Increasing the temperature of evaporator rises the average maximum temperature of the cycle, which improves the thermal efficiency of the cycle as well as the powerplant efficiency. The results show that, at higher boiler pressures and temperatures, the temperature difference between the water/steam and hot gases of the boiler is reduced which means the irreversibility associated with the heat transfer process decreases. Therefore, by increasing the pressure and temperature of the superheater, the exergy efficiency of the thermal cycle is improved. It was observed that operating the coal-fired power plant at high superheated pressure and temperatures produce lead to reduce the exergy losses.
\end{abstract}

\section{Introduction}

The first law of thermodynamics remains the most utilized method for analyzing the energy conversion of a system [1-7]. However, this first law-based energy analysis cannot provide the actual losses of the system in terms of efficiency and thermodynamic losses [1, 8-18]. Therefore, it is important that the energy conversion efficiency of a system be analyzed by considering both the first and second laws of thermodynamics [19-24]. Second law-based exergy analysis provides a better view of the energy losses to the environment and the process-related internal irreversibility. It can

\footnotetext{
* Corresponding author.

E-mail address: mechanoz86@gmail.com

* Corresponding author.

E-mail address: thamirmathcad@yahoo.com
}

https://doi.org/10.37934/arfmts.87.2.2743 
evaluate both process and devices performances as it considers the exergy at different stages during the process of energy conversion [1, 25-38]. The concept of exergy analysis was first detailed by Carnot in 1824 and furthered by Clasisus in 1865. Normally, the first law of thermodynamics (referred to as the first law of analysis) is used to determine the efficiency of a process or a system while the second law of analysis (exergy analysis) relates to entropy production and the concept of concept of irreversibility. The first law of analysis has often been used to calculate energy losses in coal-fired power plants based on the enthalpy balance [39, 40]. However, exergy analysis has gained importance recently over the first law of analysis due to the failure of the first law of analysis to provide enough results that will aid studying the performance of power plants. Exergy analysis primarily aims at identifying the locations of exergy losses, as well as study power plants in terms of their quality [1, 41-52]. Exergy analysis remains a way of locating process or system inefficiencies which first law of analysis cannot do. Exergy analysis also helps in locating the irreversibility within a system and assesses the individual system components in terms of their efficiencies [53]. The outcomes of exergy analysis also help process practitioners in refining and developing coal-fired power plants with optimal performance [54-65]. The exergy of any thermodynamic process reflects its efficiency or inefficiency and provides a better knowledge of the processes for qualifying energy. Therefore, the location, quality, and quantity of energy destruction within a system should better be established based on exergy analysis.

In this study, second law analysis is a methodology for assessment of the performance of the component and involves examining the exergy at different feedwater heaters in a series of energyconversion steps. This research attempts the development of an integrated strategy for the analysis and improvement of the overall performance of the coal-fired power plants based on the effect of operations conditions.

\section{Methodology}

In the present study, Unit 1 of Manjung Coal Fired power plant located in Malaysia is considered for investigation. The process flow diagram (PFD) of this power plant is illustrated in Figure 1 . This figure does not show the boiler and economizer sections. To analyze the complete cycle of the powerplant, the continuity, energy and exergy equations governing various components of the cycle are developed and resolved using Engineering Equation Solver (EES) software. The continuity equations are invoked to find the distribution of feed water and steam throughout the cycle. 


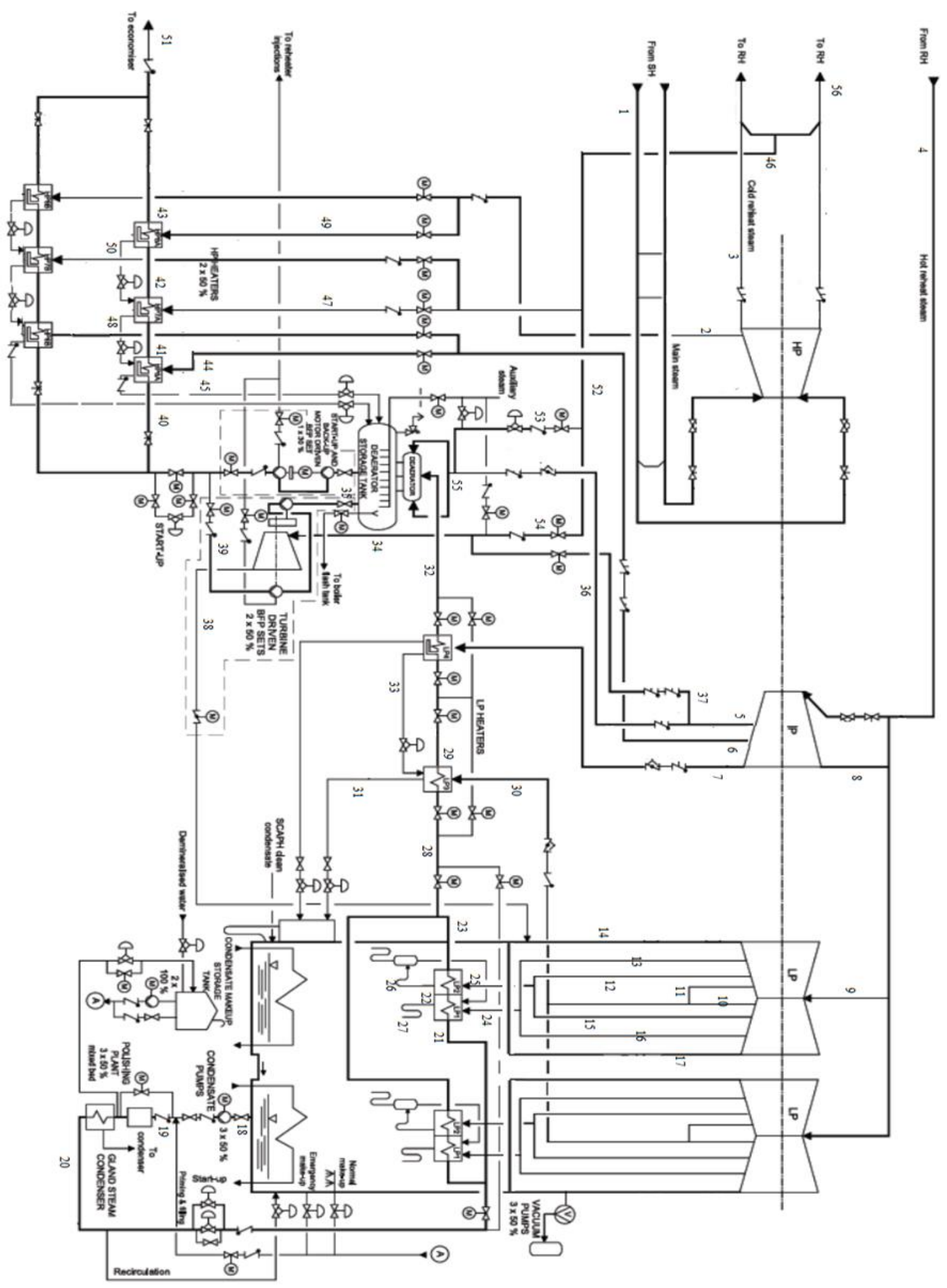

Fig. 1. Process flow diagram of the considered power plant

Table 1 summarizes the energy equations and efficiencies/effectiveness of various components of the thermal cycle; while Table 2 summarizes the exergy supply, exergy destruction and exergy efficiency of those components. 
Table 1

Energy equations and efficiencies/effectiveness of various components of the thermal cycle

\begin{tabular}{|c|c|c|}
\hline Component Name & Energy Equation & Energy Efficiency \\
\hline Boiler & $\begin{array}{l}Q_{\text {Boiler }}=m_{1} \cdot h_{1}+m_{4} \cdot h_{4} \\
\quad-m_{36} \cdot h_{36}-m_{51} \cdot h_{51}\end{array}$ & $\eta_{\text {Boiler }}=\frac{Q_{\text {Boiler }}}{m_{\text {Coal }} H H V_{\text {Coal }}}$ \\
\hline Condenser & $\begin{array}{l}Q_{\text {Cond }}=2 m_{14} \cdot h_{14}+2 m_{17} \cdot h_{17} \\
+2 m_{27} \cdot h_{27}+m_{31} \cdot h_{31}-m_{18} \cdot h_{18}\end{array}$ & NA \\
\hline Deaerator & $\begin{aligned} m_{32} \cdot h_{32}+m_{34} \cdot h_{34}+2 m_{45} \cdot h_{45} \\
-m_{35} \cdot h_{35}=0\end{aligned}$ & NA \\
\hline HPT & $W_{H P T}=m_{1} \cdot h_{1}-m_{2} \cdot h_{2}-m_{3} \cdot h_{3}$ & $\begin{aligned} & \eta_{s, H P, i}= \frac{h_{1}-h_{i}}{h_{1}-h_{i, s}} \\
& i=2,3\end{aligned}$ \\
\hline IPT & $\begin{aligned} W_{I P T}= & m_{4} \cdot h_{4}-m_{5} \cdot h_{5}-m_{6} \cdot h_{6} \\
& -m_{7} \cdot h_{7}-m_{8} \cdot h_{8}\end{aligned}$ & $\begin{aligned} & \eta_{s, I P, i}= \frac{h_{4}-h_{i}}{h_{4}-h_{i, s}} \\
& i=5, \ldots, 8\end{aligned}$ \\
\hline LPT & $W_{L P T}=2\left(m_{9} \cdot h_{9}-\sum_{i=10}^{17} m_{i} \cdot h_{i}\right)$ & $\begin{aligned} \eta_{s, L P, i}= & \frac{h_{9}-h_{i}}{h_{9}-h_{i, s}} \\
& i=10, \ldots, 17\end{aligned}$ \\
\hline BFP & $W_{B F P}=m_{35} \cdot\left(h_{35}-h_{39}\right)$ & $\eta_{s, B F P}=\frac{v_{35} \cdot\left(p_{39}-p_{35}\right)}{h_{39}-h_{35}}$ \\
\hline FWH \#1 & $\begin{array}{l}m_{21} \cdot h_{21}+m_{24} \cdot h_{24}+m_{26} \cdot h_{26} \\
-m_{22} \cdot h_{22}-m_{27} \cdot h_{27}=0\end{array}$ & $\varepsilon=\frac{T_{22}-T_{21}}{T_{24}-T_{21}}$ \\
\hline FWH's \#2, \#4, \#8 & $\begin{array}{l}m_{c, \text { in }} \cdot h_{c, \text { in }}+m_{h, \text { in }} \cdot h_{h, \text { in }} \\
-m_{c, \text { out }} \cdot h_{c, \text { out }}-m_{h, \text { out }} \cdot h_{h, \text { out }}=0\end{array}$ & $\begin{aligned} \varepsilon= & \varepsilon^{\prime} \cdot \frac{T_{c, \text { out }}-T_{c, \text { in }, b}}{T_{c, \text { out }}-T_{c, \text { in }}} \\
& +\varepsilon^{\prime \prime} \cdot \frac{T_{c, \text { in }, b}-T_{c, \text { in }}}{T_{c, \text { out }}-T_{c, \text { in }}}\end{aligned}$ \\
\hline & & $\varepsilon^{\prime}=\frac{T_{h, i n}-T_{h, s a t}}{T_{h, i n}-T_{c, i n, b}} \quad \varepsilon^{\prime \prime}=\frac{T_{c, i n, b}-T_{c, i n}}{T_{h, s a t}-T_{c, i n}}$ \\
\hline FWH's \#3, \#6, \#7 & $\begin{array}{l}m_{h, \text { in }} \cdot h_{h, \text { in }}+m_{c, \text { in }} \cdot h_{c, \text { in }} \\
+m_{\text {con, dis }} \cdot h_{\text {con }, \text { dis }}-m_{c, \text { out }} \cdot h_{c, \text { out }} \\
\quad-m_{h, \text { out }} \cdot h_{h, \text { out }}=0\end{array}$ & 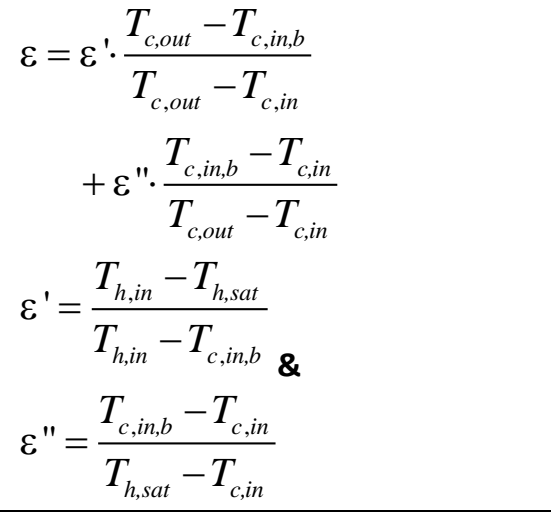 \\
\hline
\end{tabular}




\section{Table 2}

Exergy supply, destruction and efficiency of various components of the thermal cycle

\begin{tabular}{|c|c|c|c|}
\hline Component Name & Exergy Supply & Exergy Destruction & Exergy Efficiency \\
\hline Boiler & $\begin{array}{l}\operatorname{Exs}_{\text {Boiler }}=E x_{\text {Chem,Coal }} \\
E x_{\text {Chem,Coal }}=\varphi L H V \\
\varphi=1.0437+ \\
0.1896(h / c)+ \\
0.2499(o / c)+ \\
0.0428(n / c)\end{array}$ & $\begin{array}{l}E x d_{\text {Boiler }}=E x_{\text {Chem,Coal }} \\
-\left(\begin{array}{l}E x_{1}+E x_{4}-E x_{51} \\
-E x_{36}\end{array}\right)\end{array}$ & $\eta_{2, \text { Boiler }}=\frac{E x_{1}+E x_{4}-E x_{51}-E x_{36}}{E x_{\text {Chem }, \text { Coal }}}$ \\
\hline Condenser & $\begin{array}{l}E x S_{\text {cond }}=E x_{27}+ \\
2 E x_{14}+2 E x_{17}+ \\
E x_{31}+E x_{52}\end{array}$ & $\begin{array}{l}E x d_{\text {condenser }} \\
=E x s_{\text {condenser }}-\left(E x_{53}\right. \\
\left.-E x_{18}\right)\end{array}$ & $\eta_{2, \text { condenser }}=1-\frac{E x d_{\text {condenser }}}{E x s_{\text {condenser }}}$ \\
\hline Deaerator & $\begin{array}{r}E x s_{\text {deaerator }}=E x_{32}+ \\
E x_{34}+2 E x_{45}\end{array}$ & $\begin{array}{l}\operatorname{Exd}_{\text {deaerator }}=T_{0} S_{\text {gen }}= \\
T_{0}\left(\begin{array}{l}m_{35} s_{35}-m_{32} s_{32}- \\
m_{34} s_{34}-2 m_{45} s_{45}\end{array}\right)\end{array}$ & $\eta_{2, \text { deaerator }}=1-\frac{E x d_{\text {deaerator }}}{E x s_{\text {deaerator }}}$ \\
\hline HPT & $\begin{aligned} E x s_{H P T}=E x_{1} & -E x_{2} \\
& -E x_{3}\end{aligned}$ & $\begin{aligned} e x d_{H P T}= & E x s_{H P T} \\
& -W_{H P T}\end{aligned}$ & $\eta_{2 s, H P T}=\frac{W_{H P T}}{E x s_{H P T}}$ \\
\hline IPT & $\begin{array}{l}E x s_{I P T}=E x_{4}-E x_{5} \\
-E x_{6}-E x_{7}-E x_{8}\end{array}$ & $E x d_{I P T}=E x s_{I P T}-W_{I P T}$ & $\eta_{2 s, I P T}=\frac{W_{I P T}}{E x s_{I P T}}$ \\
\hline LPT & $\begin{array}{l}E x s_{L P T}=2 E x_{9} \\
-2\left(\sum^{17} E x_{i}\right)\end{array}$ & $\begin{aligned} E x d_{L P T}= & E x s_{L P T} \\
& -W_{L P T}\end{aligned}$ & $\eta_{2 s, L P T}=\frac{W_{L P T}}{E x S_{L P T}}$ \\
\hline BFP & $E x s_{B F P}=W_{B F P}$ & $\begin{array}{l}E x d_{B F P}=W_{B F P} \\
-\left(E x_{39}-E x_{35}\right)\end{array}$ & $\eta_{2 s, B F P}=\frac{E x_{39}-E x_{35}}{W_{B F P}}$ \\
\hline FWH \#1 & $\begin{aligned} E x s_{F W H 1}=E x_{24} & +E x_{26 b} \\
& -E x_{27}\end{aligned}$ & $\begin{array}{l}E x d_{F W H 1}=E x s_{F W H 1} \\
-\left(E x_{22}-E x_{21}\right)\end{array}$ & $\eta_{2, F W H 1}=\frac{E x_{22}-E x_{21}}{E x_{24}+E x_{26 b}-E x_{27}}$ \\
\hline $\mathrm{FWH}^{\prime} \mathrm{s} \# 2, \# 4, \# 8$ & $E x s=E x_{h, \text { in }}-E x_{h, \text { out }}$ & $\begin{array}{l}E x d=E x s \\
-\left(E x_{c, \text { out }}-E x_{c, \text { in }}\right)\end{array}$ & $\eta_{2}=\frac{E x_{c, \text { out }}-E x_{c, \text { in }}}{E x_{h, \text { in }}-E x_{h, \text { out }}}$ \\
\hline FWH's \#3, \#6, \#7 & $\begin{aligned} E x s=E x_{h, \text { in }} & +E x_{c o n, d i s} \\
& -E x_{h, \text { out }}\end{aligned}$ & $\begin{array}{l}E x d=E x s \\
\qquad-\left(E x_{c, \text { out }}-E x_{c, \text { in }}\right)\end{array}$ & $\eta_{2}=\frac{E x_{c, \text { out }}-E x_{c, \text { in }}}{E x_{h, \text { in }}+E x_{c o n, d i s}-E x_{h, \text { out }}}$ \\
\hline
\end{tabular}

In this investigation, Unit 1 of Manjung Coal Fired Power plant located in Malaysia is considered for analysis. This unit produces $700 \mathrm{MW}$ nominally; while according to the acquired data, its actual output is around $590 \mathrm{MW}$. To have a solid ground for comparison and analysis, a baseline case is assumed. Solving the governing equations developed, different parameters of the power plant are evaluated for the baseline case

\section{Results and Discussion}

In this section, the impact of changing conditions at different points of the cycle on the main parameters of the cycle and power plant are presented and analyzed. Based on the results, we can conclude what would happen if this situation convey in the real power plant. In fact, in this mode, 
we assume that the power plant has already been designed and manufactured and is currently in operation. Therefore, different components of the power plant are fixed and cannot be varied. In the following, the effect of changing the thermal cycle conditions on the energy and exergy parameters of the power plant are depicted.

\subsection{Superheater Outlet Pressure}

The variations of the effectiveness of the feed water heaters with the pressure of the steam exiting the superheater and entering the high pressure turbine are illustrated in Figure 2. It is seen from this figure that heaters \#7 and \#8 experience remarkable changes with the variation of superheater pressure; while the effectiveness values of other heaters are approximately invariant. This is expectable as changing the superheater pressure mainly changes the steam bled from high pressure turbine and fed to heaters \#7 and \#8. From the figure, it is observed that increasing the superheater pressure will enhance the effectiveness of heaters \#7 and \#8. This can be reasoned as following. In all of the feed water heaters except heater \#1, the bled steam enters in superheated condition. Therefore, the heaters are composed of two sections: desuperheating section and condensing section. The effectiveness of the condensing section is higher than that of the desuperheating section, because the convection heat transfer coefficient of the condensation is much higher than that of a single phase gas. Considering this matter, we need to note that we have increased the superheater pressure while its temperature is kept fixed. That is, the steam entering the HPT is closer to the saturated vapor curve (possessing lower entropy). Thus, in this case, the desuperheating section will mitigate resulting in higher effectiveness values.

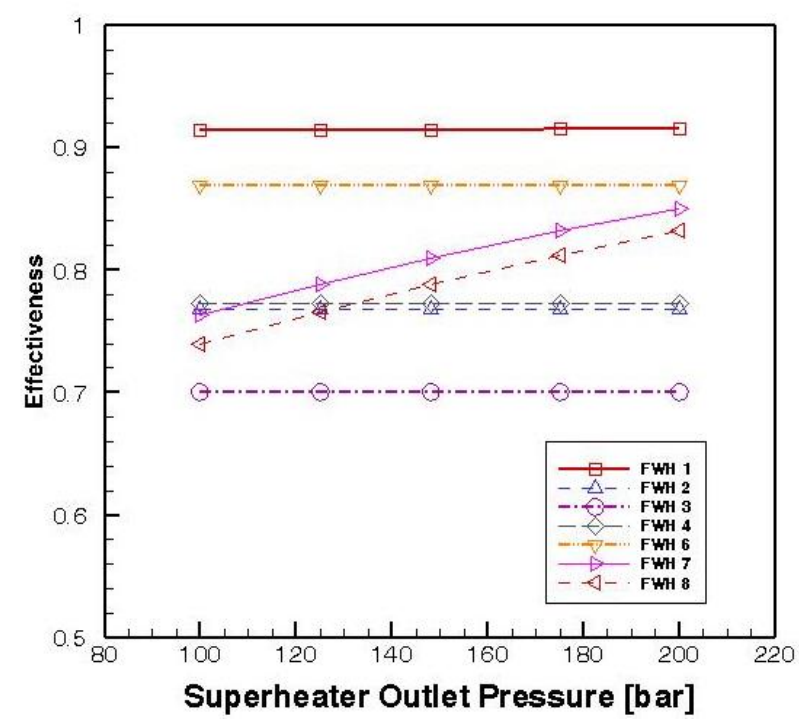

Fig. 2. Variations of FWH's effectiveness with the superheater outlet pressure

The impacts of the superheater pressure on the thermal efficiency and the powerplant efficiency are depicted in Figure 3. It is observed from this figure that higher superheater pressures lead to higher energy based efficiencies. This is due to the increment of the temperature of the evaporator which corresponds to the superheater pressure. In fact, increasing the temperature of evaporator rises the average maximum temperature of the cycle which improves the thermal efficiency of the cycle as well as the powerplant efficiency. This is totally in agreement with what we expect from thermodynamics. 


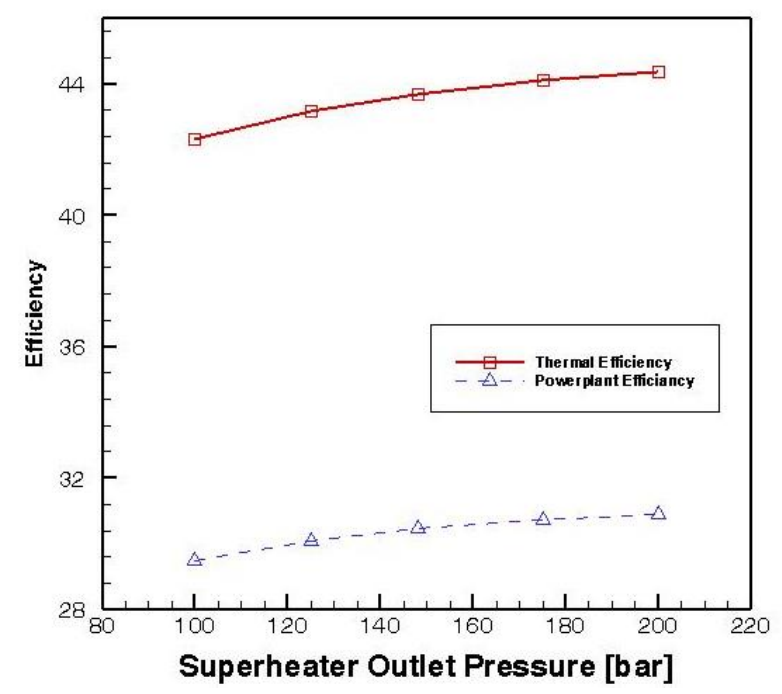

Fig. 3. The effect of superheater outlet pressure on thermal efficiencies of the cycle and power plant

Figure 4 shows the variations of exergy efficiency of the cycle versus superheater pressure. Here again, the higher superheated steam pressures cause higher exergy efficiencies. This is because, at higher boiler pressures, the temperature difference between the water/steam and hot gases of the boiler is reduced which means the irreversibility associated with the heat transfer process decreases. Therefore, by increasing the pressure of the superheater, the exergy efficiency of the thermal cycle is improved.

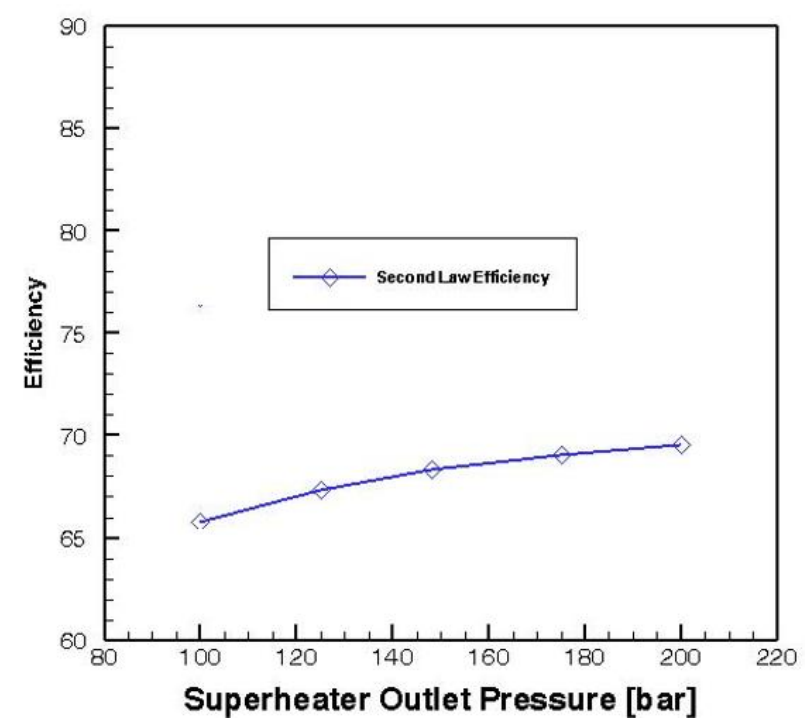

Fig. 4. The effect of superheater outlet pressure on the exergy efficiency of the cycle

The variations of the fuel consumption rate, heat rate of the cycle and the net power delivered by the cycle with the superheater pressure are given in Table 3. From this table, it is clear that increasing the superheater pressure increases the coal consumption moderately; that is, by increasing the superheater pressure by $100 \%$, the coal consumption rate just increases up to $3 \%$; while the net power delivered by the cycle increases more than $8 \%$. It is because that, the coal 
consumption was increasing so steam mass flow rate will increases too. This shows the importance of increasing the pressure of the superheater. This issue is also reflected in the heat rate of the cycle. As is seen from the table, increasing the superheater pressure from 100 to 200 bar lowers the heat rate of the cycle from 2.364 to 2.254 .

\section{Table 3}

The effect of superheater outlet pressure on the Heat Rate of the cycle, net power delivered by the cycle and mass flow rate of coal consumed in the boiler

\begin{tabular}{llcc}
\hline $\begin{array}{l}\text { Superheater Outlet } \\
\text { Pressure [bar] }\end{array}$ & $\dot{m}_{\text {Coal }}[\mathrm{kg} / \mathrm{s}]$ & HRcycle & $\dot{W}_{\text {net }}[\mathrm{MW}]$ \\
\hline 100 & 86.32 & 2.364 & 559.330 \\
125 & 87.47 & 2.316 & 578.333 \\
148.1 & 88.17 & 2.288 & 590.234 \\
175 & 88.70 & 2.266 & 599.472 \\
200 & 88.98 & 2.253 & 604.844 \\
\hline
\end{tabular}

Figure 5 represents the variation of exergy efficiencies of different turbines versus the superheater pressure. As changing, the pressure of superheater has no tangible effect on IPT and LPT, the exergy efficiencies of these turbines do not vary with superheater pressure, expectedly. However, the exergy efficiency of HPT decreases with the increase in the superheater pressure. Because, increasing the pressure of the steam entering HPT while its temperature is kept fixed, shifts the steam state towards the saturation vapor line. Hence, the specific volume of steam decreases and the steam enters the saturation dome sooner, which leads to higher irreversibility.

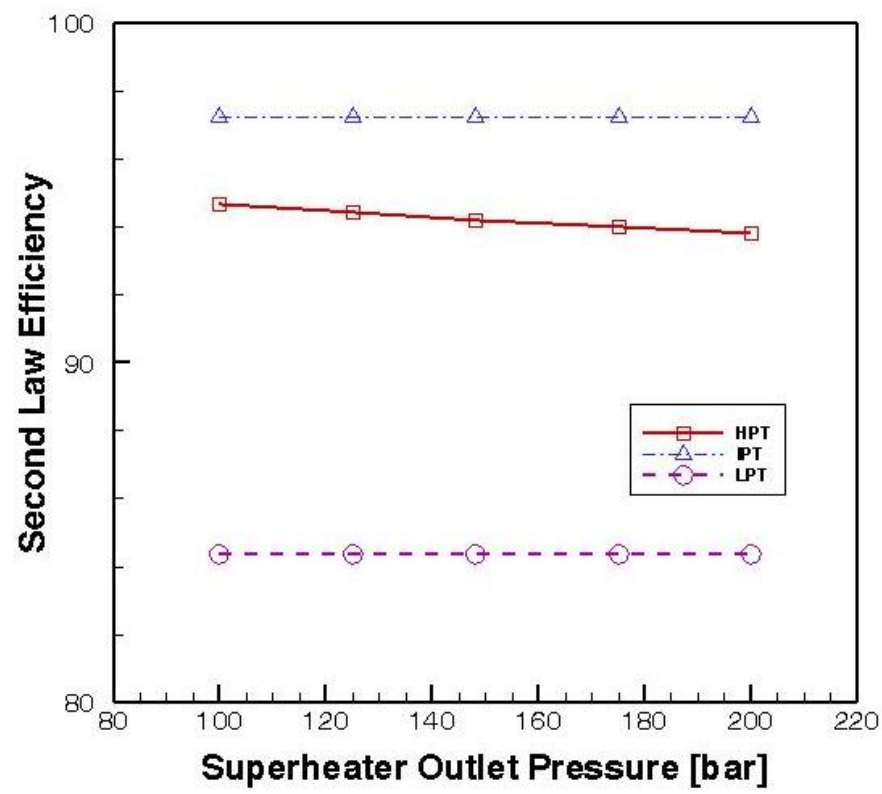

Fig. 5. Effect of the superheater outlet pressure on the second law efficiencies of different turbines

The dependency of the exergy efficiency of different feed water heaters on the superheater pressure is shown in Figure 6. Here, it is seen that the second law efficiencies of the low pressure heaters; i.e. heaters \#1-\#5 are not affected by the superheater pressure changes. However, the exergy efficiency of heaters \#6-\#8 are improved with the superheater pressure rise. Similar to what was discussed for Figure 5, higher superheater pressures lead to the shift of the states of the extracted steam from HPT towards the saturated vapor line. Thus, the temperature difference in the 
heaters will reduce. Therefore, the entropy generation and irreversibility associated with the heat transfer inside the heaters will mitigate.

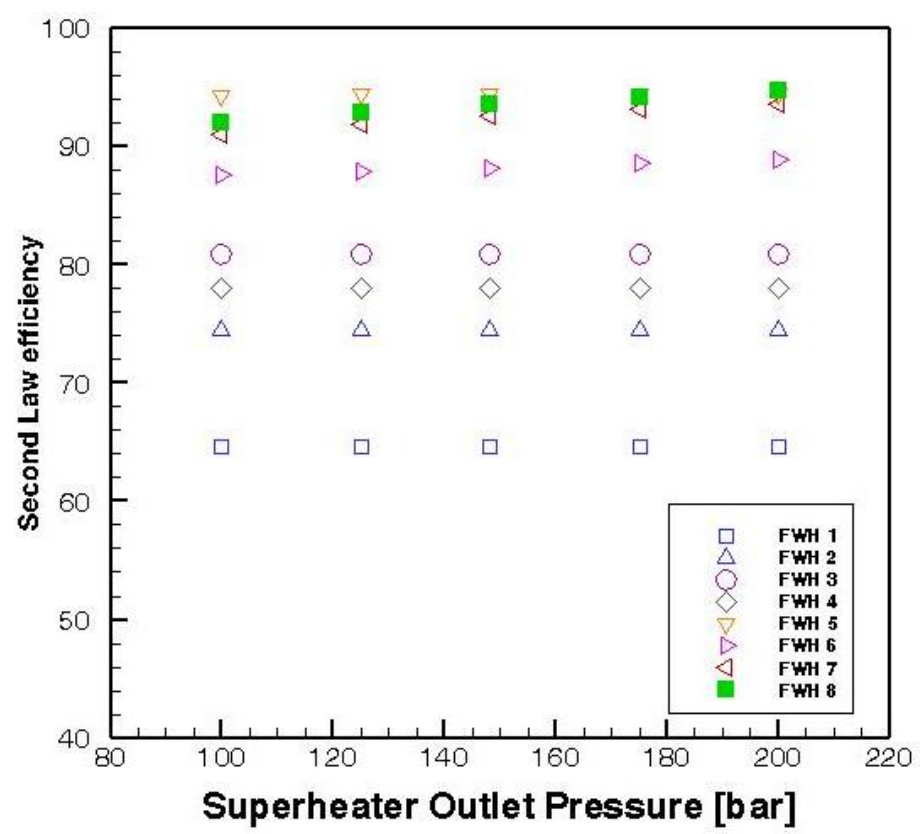

Fig. 6. Effect of the superheater outlet pressure on the exergy efficiencies of the heaters

\subsection{Superheater Outlet Temperature}

Graphed in Figure 7 are the variations of the effectiveness of the feed water heaters with the temperature of the steam exiting the superheater and entering the high pressure turbine. As the temperatures of the steam streams after the superheater and after the reheater are always of the same order, we assumed that this correlation conveys between these temperatures. That is, any change in the temperature of the superheated steam entering the HPT will change the temperature of the reheated steam entering IPT.

From figure 7, it is seen that the effectiveness of the high pressure heaters deteriorates with the increase of the superheater outlet temperature. The reasoning is similar to that of Figure 2; however the trend is reverse. Here, by increasing the superheater outlet temperature while the pressure is kept fixed, the bled steam deviates more from the saturated vapor line. Therefore, the desuperheating section extends which leads to lower effectiveness values. It is noteworthy that the effectiveness of the condensing section is not affected by changing the superheater outlet temperature. Moreover, the effectiveness values of the low pressure heaters are approximately invariant. This result is consistent with what was seen in Figure 2. 


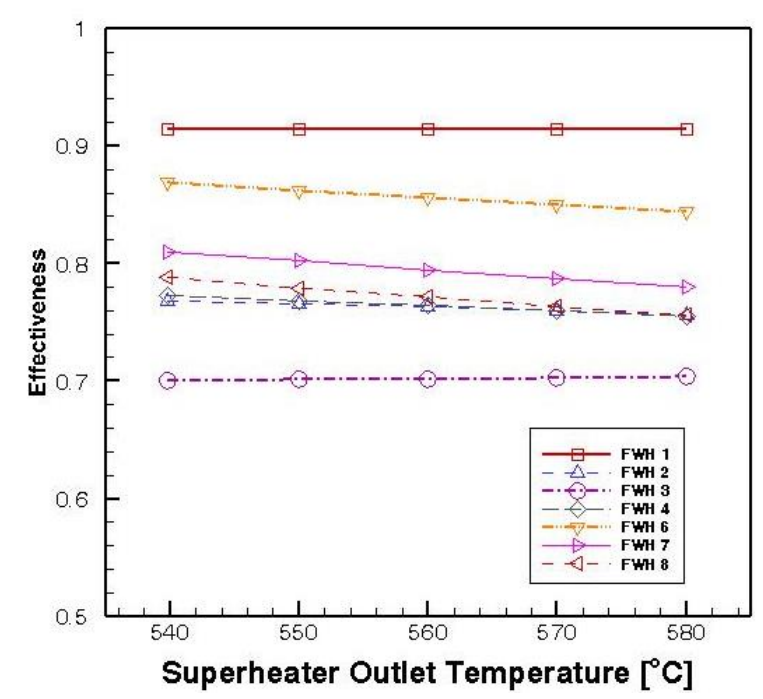

Fig. 7. Variations of FWH's effectiveness with the superheater outlet temperature

The effect of increasing the temperature of the steam exiting the superheater on the thermal efficiency and the power plant efficiency are illustrated in Figure 8. It is observed from this figure that the higher superheated steam temperatures correspond to higher thermal and power plant efficiencies. This is due to the increment of the average temperature of the steam passing through the whole boiler including economizer, evaporator and superheater sections, while the pressure and thus the temperature of the condenser are kept fixed.

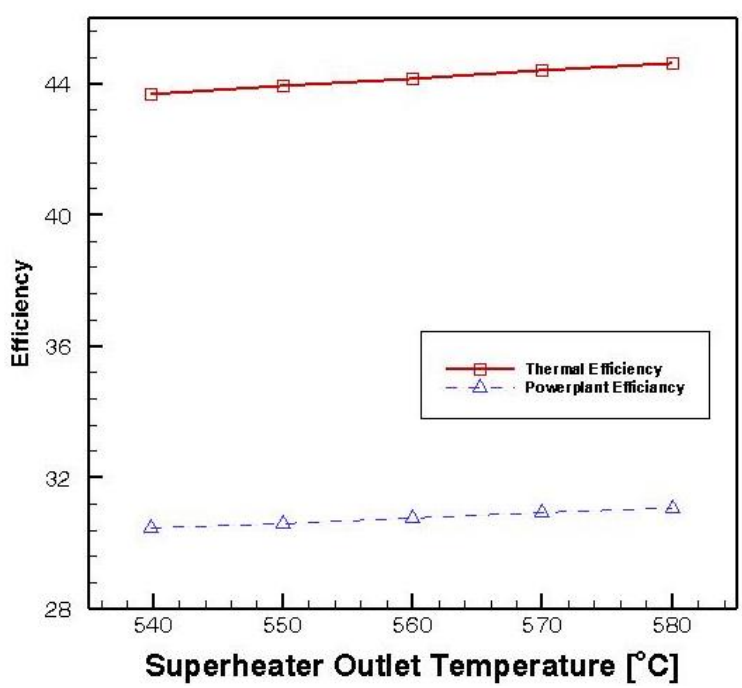

Fig. 8. The effect of superheater outlet temperature on thermal efficiencies of the cycle and powerplant

Figure 9 shows the variations of the exergy efficiency of the cycle versus the inlet temperature of the steam entering high pressure turbine. From this figure, it is evident that the higher superheated steam temperatures result in higher exergy efficiencies. Similar to what presented in Figure 3 , this is because, at higher boiler temperatures, the temperature gap between the water/steam and hot gas streams is reduced leading to lower irreversibility associated with the heat transfer across finite 
temperature gaps. Therefore, by increasing the temperature of the superheated steam, the exergy efficiency of the thermal cycle is enhanced.

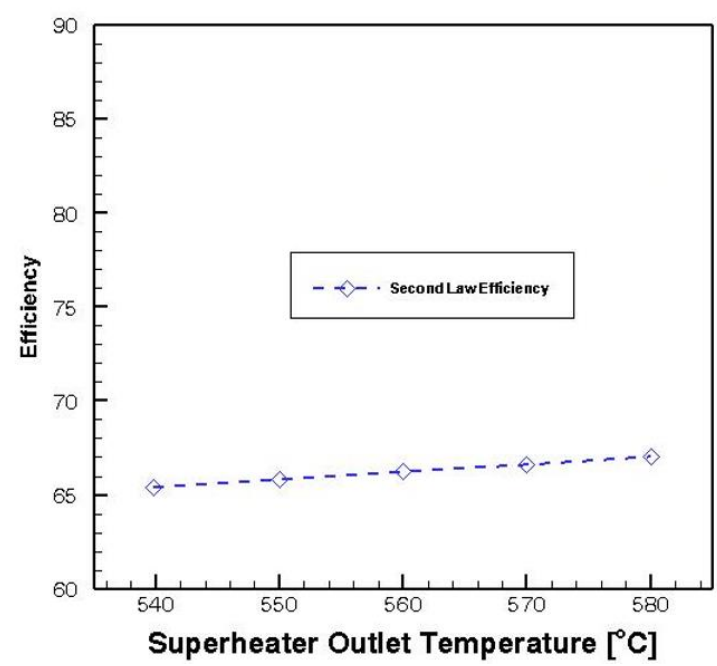

Fig. 9. The effect of superheater outlet temperature on the exergy efficiency of the cycle

Table 4 gives the variations of the fuel consumption rate, heat rate of the cycle and the net power delivered by the cycle with the temperature of the superheated steam entering the high pressure turbine. From this table, it is seen that the coal consumption is increased by the increment of the superheated steam temperature. By increasing the superheated steam temperature from 539.8 to $580^{\circ} \mathrm{C}$, the coal consumption rate increases around $4 \%$; while the net power delivered by the cycle increases more than $6 \%$. This shows the role of increasing the temperature of the superheated steam. From the heat rate standpoint, it is seen that increasing the superheated steam temperature from 539.8 to $580^{\circ} \mathrm{C}$, reduces the heat rate of the cycle from 2.288 down to 2.242 .

\section{Table 4}

The effect of superheater outlet temperature on the Heat Rate of the cycle, net power delivered by the cycle and mass flow rate of coal consumed in the boiler

\begin{tabular}{llcc}
\hline $\begin{array}{l}\text { Superheater Outlet } \\
\text { Temperature }\left[{ }^{\circ} \mathrm{C}\right]\end{array}$ & $\dot{m}_{\text {Coal }}[\mathrm{kg} / \mathrm{s}]$ & $\mathrm{HR}_{\text {cycle }}$ & $\dot{W}_{\text {net }}[\mathrm{MW}]$ \\
\hline 539.8 & 88.17 & 2.288 & 590.234 \\
550 & 89.10 & 2.275 & 599.693 \\
560 & 90.01 & 2.264 & 608.966 \\
570 & 90.92 & 2.252 & 618.241 \\
580 & 91.82 & 2.241 & 627.523 \\
\hline
\end{tabular}

Figure 10 represents the variation of exergy efficiencies of different turbines with the superheater outlet temperature. Similar to Figure 5, as the change in the temperature of the superheated steam entering HPT has slight effect on IPT and LPT, the exergy efficiency of these turbines do not vary with superheated steam temperature, remarkably. However, the exergy efficiency of HPT is enhanced with the increase in the superheated steam temperature. Because, increasing the temperature of the steam entering HPT while its pressure is kept fixed dislocates the steam state further from the saturation vapor line. Hence, the specific volume of steam increases and the steam entrance into the saturation dome is delayed which leads to lower irreversibilities. 


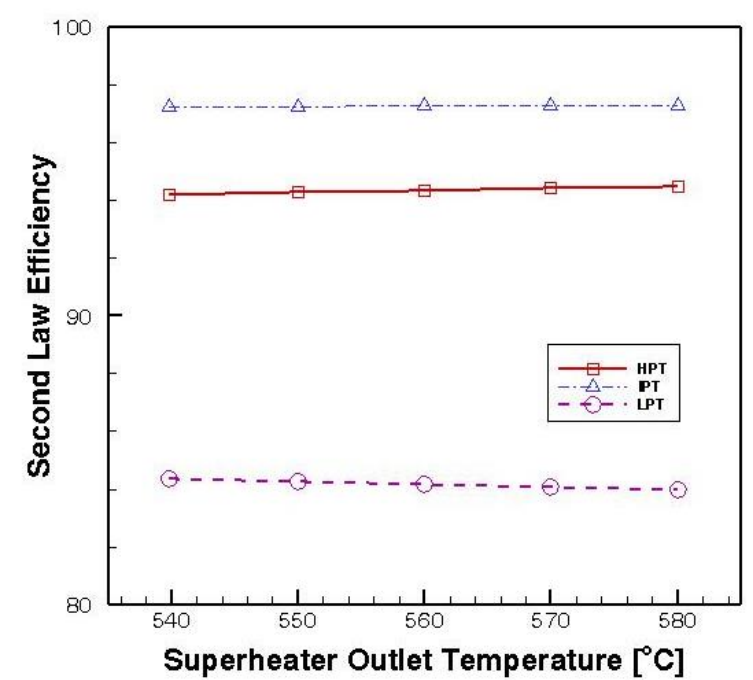

Fig. 10. Effect of the superheater outlet temperature on the second law efficiencies of different turbines

The second law efficiency of different feed water heaters varies with the superheated steam temperature as shown in Figure 11. It is seen that all the exergy efficiencies are reduced by increasing the temperature of the superheated steam, slightly. Unlike what we have seen in Figure 6, here the behavior of all the heaters is similar, because the temperature of the reheated steam is also increased. Moreover, the reason for this descending behavior lies in this fact that increasing the superheated steam temperature expands the region of desuperheating sections of the heaters which possess higher temperature gaps between the streams.

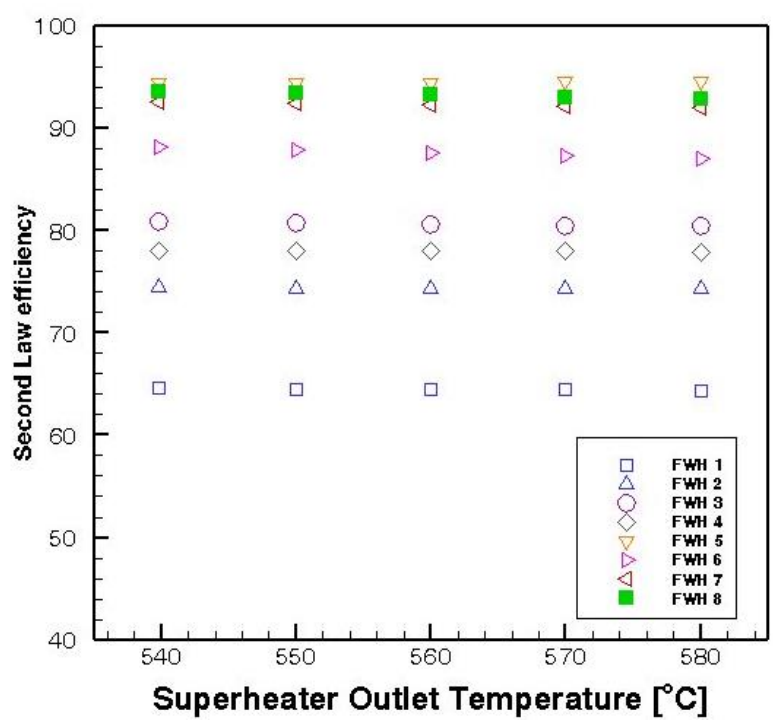

Fig. 11. Effect of the superheater outlet temperature on the exergy efficiencies of the heaters 


\section{Conclusion}

This study is devoted to analyze a coal-fired power plant, to investigate the impact of the operational conditions as well as different configurations of the feed water heaters on the energy and exergy performances of the coal-fired power plant.

i. Higher superheater pressures lead to higher energy and exergy based efficiencies.

ii. By increasing the superheater pressure by $100 \%$, the net power delivered by the cycle increases more than $8 \%$.

iii. By increasing the superheated steam temperature from 539.8 to $580^{\circ} \mathrm{C}$, the net power delivered by the cycle increases more than $6 \%$.

iv. The main impact of superheated steam temperature is observed in the exergy supplies and destructions to/at FWH's \#1 (3.78\%), \#4 (3.58\%) and \#6 (4.33\%) which receive steam from the LPT, IPT and IPT, respectively.

v. The exergy efficiency of heaters \#2 is increased by increasing the temperature of the superheated steam; while the behavior of other closed feed water heaters is reverse.

\section{Acknowledgment}

The authors would like to thank Universiti Tenaga Nasional (UNITEN) for providing laboratory facilities and financial support.

\section{References}

[1] Deng, Chao, Ahmed T. Al-Sammarraie, Thamir K. Ibrahim, Erfan Kosari, Firdaus Basrawi, Firas B. Ismail, and Ahmed N. Abdalla. "Air cooling techniques and corresponding impacts on combined cycle power plant (CCPP) performance: A review." International Journal of Refrigeration (2020). https://doi.org/10.1016/j.jirefrig.2020.08.008

[2] Zaidan, Maki H., Aadel AR Alkumait, and Thamir K. Ibrahim. "Assessment of heat transfer and fluid flow characteristics within finned flat tube." Case studies in thermal engineering 12 (2018): 557-562. https://doi.org/10.1016/i.csite.2018.07.006

[3] Awad, Omar I., R. Mamat, Thamir K. Ibrahim, Ftwi Y. Hagos, M. M. Noor, I. M. Yusri, and A. M. Leman. "Calorific value enhancement of fusel oil by moisture removal and its effect on the performance and combustion of a spark ignition engine." Energy conversion and management $137 \quad$ (2017): https://doi.org/10.1016/i.enconman.2017.01.009

[4] Ibrahim, Thamir K., Mohammed Kamil Mohammed, Omar I. Awad, Ahmed N. Abdalla, Firdaus Basrawi, Marwah N. Mohammed, G. Najafi, and Rizalman Mamat. "A comprehensive review on the exergy analysis of combined cycle power plants." Renewable and Sustainable Energy Reviews 90 (2018): 835-850. https://doi.org/10.1016/i.rser.2018.03.072

[5] Vasu, Anusuiah, Ftwi Y. Hagos, M. M. Noor, R. Mamat, W. H. Azmi, Abdul A. Abdullah, and Thamir K. Ibrahim. "Corrosion effect of phase change materials in solar thermal energy storage application." Renewable and Sustainable Energy Reviews 76 (2017): 19-33. https://doi.org/10.1016/i.rser.2017.03.018

[6] Mhamuad, Aziz7 M., Thamir Kh Ibrahim, and Raid R. Jasim. "Determination of the temperature distribution the perforated fins under." Tikrit Journal of Engineering Sciences 15, no. 2 (2008): 63-78.

[7] Ibrahim, Thamir K., and M. M. Rahman. "Effect of compression ratio on the performance of different strategies for the gas turbine." International Journal of Automotive and Mechanical Engineering 9 (2014): 1747. https://doi.org/10.15282/ijame.9.2013.23.0145

[8] Basrawi, Firdaus, Thamir K. Ibrahim, Khairul Habib, and Takanobu Yamada. "Effect of operation strategies on the economic and environmental performance of a micro gas turbine trigeneration system in a tropical region." Energy 97 (2016): 262-272. https://doi.org/10.1016/i.energy.2015.12.117

[9] Ibrahim, Thamir K., Firdaus Basrawi, Marwah Noori Mohammed, and Hassan Ibrahim. "Effect of perforation area on temperature distribution of the rectangular fins under natural convection." ARPN Journal of Engineering and Applied Sciences 11, no. 10 (2016): 6371-6375.

[10] Basrawi, Firdaus, Thamir K. Ibrahim, Giok Chui Lee, Khairul Habib, and Hassan Ibrahim. "Effect of solar fraction on the economic and environmental performance of solar air-conditioning by adsorption chiller in a tropical region." Journal of Solar Energy Engineering 137, no. 6 (2015). https://doi.org/10.1115/1.4031707 
[11] Ibrahim, Thamir K., and M. M. Rahman. "Effective Parameters on Performance of Multipressure Combined Cycle Power Plants." Advances in Mechanical Engineering (Hindawi Publishing Corporation) (2014). https://doi.org/10.1155/2014/781503

[12] Ibrahim, Thamir K., and M. M. Rahman. "Effects of cycle peak temperature ratio on the performance of combined cycle power plant." International Journal of Automotive \& Mechanical Engineering 13, no. 2 (2016). https://doi.org/10.15282/ijame.13.2.2016.8.0280

[13] Awad, Omar I., Rizalman Mamat, Thamir K. Ibrahim, Maurice Kettner, K. Kadirgama, A. M. Leman, and A. I. M. Saiful. "Effects of fusel oil water content reduction on fuel properties, performance and emissions of SI engine fueled with gasoline-fusel oil blends." Renewable energy 118 (2018): 858-869. https://doi.org/10.1016/i.renene.2017.11.071

[14] Ibrahim, Thamir K., and M. M. Rahman. "Effects of isentropic efficiencies on the performance of combined cycle power plants." International Journal of Automotive \& Mechanical Engineering 12 (2015). https://doi.org/10.15282/ijame.12.2015.9.0244

[15] Ibrahim, Thamir K., and M. M. Rahman. "Effects of isentropic efficiency and enhancing strategies on gas turbine performance." Journal of Mechanical Engineering and Sciences $4 \quad$ (2013): 383-96. https://doi.org/10.15282/imes.4.2013.3.0036

[16] Ibrahim, Thamir K., and M. M. Rahman. "Effects of operation conditions on performance of a gas turbine power plant." In National Conference in Mechanical Engineering Research and Postgraduate Studies (2nd NCMER 2010), pp. 135-144. Faculty of Mechanical Engineering, UMP Pekan, 2010.

[17] Mohammed, Mohammed Kamil, Wadhah Hussein Al Doori, Ataalah Hussain Jassim, Thamir Khalil Ibrahim, and Ahmed Tawfeeq Al-Sammarraie. "Energy and exergy analysis of the steam power plant based on effect the numbers of feed water heater." Journal of Advanced Research in Fluid Mechanics and Thermal Sciences 56, no. 2 (2019): 211 222.

[18] Elghool, Ali, Firdaus Basrawi, Hassan Ibrahim, Thamir Khalil Ibrahim, M. Ishak, T. M. Yusof, and Salem Abdullah Bagaber. "Enhancing the performance of a thermo-electric generator through multi-objective optimisation of heat pipes-heat sink under natural convection." Energy conversion and management 209 (2020): 112626. https://doi.org/10.1016/i.enconman.2020.112626

[19] Xiong, Xiu, Li Li, and Xiao-qing Zhou. "Numerical Analysis and Optimization Research on Backflow Effect of Cooling Tower." Procedia engineering 205 (2017): 2003-2010. https://doi.org/10.1016/i.proeng.2017.10.073

[20] WafirulHadi, Mohamad, Titin Trisnadewi, and Nandy Putra. "Thermal Management System Based on Phase Change Material (PCM) and Heat Pipe in Lithium-ion Electric Vehicle Batteries." Journal of Advanced Research in Experimental Fluid Mechanics and Heat Transfer 3, no. 1 (2021): 26-35.

[21] Idris, Muhammad Syafiq, Irnie Azlin Zakaria, and Wan Azmi Wan Hamzah. "Heat Transfer and Pressure Drop of Water Based Hybrid Al2O3: SiO2 Nanofluids in Cooling Plate of PEMFC." Journal of Advanced Research in Numerical Heat Transfer 4, no. 1 (2021): 1-13.

[22] Alawi, Omer A., and Haslinda Mohamed Kamar. "Performance of Solar Thermal Collector Using Multi-Walled Carbon Nanotubes: Simulation Study." Journal of Advanced Research in Micro and Nano Engineering 2, no. 1 (2020): 12-21.

[23] Ab Razak, Nur Hidayah, Nik Ahmad Nizam, Juan Matmin, Wan Rosmiza Zana Wan Dagang, Nurliyana Ahmad Zawawi, and Tejpal Singh Chundawat. "Brief Review on Bioresources Green Synthesis of Silver Nanoparticles." Journal of Advanced Research in Materials Science 79, no. 1 (2021): 1-10.

[24] Rabby, Md Insiat Islam, Siti Ujila Masuri, Ahmad Syakir Fariz Samsul Kamal, Zulkiflle Leman, Abdul Aziz Hairuddin, and Nuraini Abdul Aziz. "Flow Characteristics of Disk Bypass Pipeline Inspection Gauge (PIG) in Natural Gas Pipelines using Computational Fluid Dynamics." CFD Letters 13, no. 4 (2021): 11-37. https://doi.org/10.37934/cfdl.13.4.1137

[25] Kamil, Mohammed, Khalid Mustafa Ramadan, Omar I. Awad, Thamir K. Ibrahim, Abrar Inayat, and Xiao Ma. "Environmental impacts of biodiesel production from waste spent coffee grounds and its implementation in a compression ignition engine." Science of The Total Environment 675 (2019): 13-30. https://doi.org/10.1016/j.scitotenv.2019.04.156

[26] Basrawi, Firdaus, Yeong C. Leon, Thamir K. Ibrahim, Mohd Hazwan Yusof, A. A. Razak, Shaharin Anuar Sulaiman, and Takanobu Yamada. "Experimental Analysis on the Effect of Area of Surface Cooling for a Water-Cooled Photovoltaic." In MATEC Web of Conferences, vol. 225, p. 01011. EDP Sciences, 2018. https://doi.org/10.1051/matecconf/201822501011

[27] Ibrahim, Thamir K., Ahmed T. Al-Sammarraie, Wadhah H. Al-Taha, Mohammad Reza Salimpour, Manar Al-Jethelah, Ahmed N. Abdalla, and Hai Tao. "Experimental and numerical investigation of heat transfer augmentation in heat sinks using perforation technique." Applied Thermal Engineering $160 \quad$ (2019): 113974. https://doi.org/10.1016/j.applthermaleng.2019.113974

[28] Mohammed, Mohammed K., M. Kh Abdolbaqi, Thamir K. Ibrahim, Rizalman Bin Mamat, and Omar I. Awad.

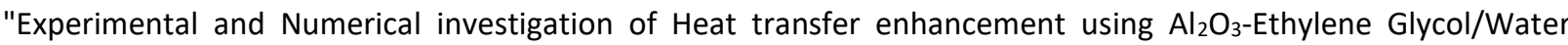


nanofluids in straight channel." In MATEC Web of Conferences, vol. 225, p. 01019. EDP Sciences, 2018. https://doi.org/10.1051/matecconf/201822501019

[29] Basrawi, Firdaus, Thamir K. Ibrahim, Surendran S. Sathiyaseelan, and A. A. Razak. "Experimental investigation on performance of solar-powered attic ventilation." In Sustainable Thermal Power Resources Through Future Engineering, pp. 1-19. Springer, Singapore, 2019. https://doi.org/10.1007/978-981-13-2968-5 1

[30] Ibrahim, Thamir K., Marwah N. Mohammed, Mohammed Kamil Mohammed, G. Najafi, Nor Azwadi Che Sidik, Firdaus Basrawi, Ahmed N. Abdalla, and S. S. Hoseini. "Experimental study on the effect of perforations shapes on vertical heated fins performance under forced convection heat transfer." International Journal of Heat and Mass Transfer 118 (2018): 832-846. https://doi.org/10.1016/i.ijheatmasstransfer.2017.11.047

[31] Ibrahim, Thamir K., Ahmed T. Al-Sammarraie, Manar SM Al-Jethelah, Wadhah H. Al-Doori, Mohammad Reza Salimpour, and Hai Tao. "The impact of square shape perforations on the enhanced heat transfer from fins: Experimental and numerical study." International Journal of Thermal Sciences 149 (2020): 106144. https://doi.org/10.1016/j.ijthermalsci.2019.106144

[32] Awad, Omar I., Rizalman Mamat, M. M. Noor, Thamir K. Ibrahim, I. M. Yusri, and A. F. Yusop. "The impacts of compression ratio on the performance and emissions of ice powered by oxygenated fuels: A review." Journal of the Energy Institute 91, no. 1 (2018): 19-32. https://doi.org/10.1016/i.joei.2016.09.003

[33] Deng, Chao, Ahmed N. Abdalla, Thamir K. Ibrahim, MingXin Jiang, Ahmed T. Al-Sammarraie, and Jun Wu. "Implementation of Adaptive Neuro-fuzzy Model to Optimize Operational Process of Multiconfiguration GasTurbines." Advances in High Energy Physics 2020 (2020). https://doi.org/10.1155/2020/6590138

[34] Ibrahim, Thamir K., M. M. Rahman, and Ahmed N. Abdalla. "Improvement of gas turbine performance based on inlet air cooling systems: A technical review." International journal of physical sciences 6, no. 4 (2011): 620-627.

[35] Ibrahim, Thamir K., M. Rahman, and K. Sharma. "Influence of operation conditions on performance of combined cycle gas turbine." In International Conference on Mechanical and Electrical Technology, 3rd,(ICMET-China 2011), vol. 1, pp. 9-15. 2011.

[36] Elghool, Ali, Firdaus Basrawi, Hassan Ibrahim, and Thamir Ibrahim. "Investigation on the performance of a prototype of thermo-electric generation with heat pipe-heat sink." In MATEC Web of Conferences, vol. 131, p. 01005. EDP Sciences, 2017. https://doi.org/10.1051/matecconf/201713101005

[37] Ibrahim, Thamir K. "The Life cycle assessments of gas turbine using inlet air cooling system." Tikrit Journal of Engineering Sciences 22, no. 1 (2015): 69-75.

[38] Al-Sammarraie, Ahmed Tawfeeq Ahmed, Raaid Rashad Jassem, and Thamir K. Ibrahim. "Mixed convection heat transfer in inclined tubes with constant heat flux." European Journal of Scientific Research 97, no. 1 (2013): 144158.

[39] Gwosdz, Alfred, and Alfons Leisse. "Pulverized coal firing system for the operation of steam generators with low excess air." GB POWERTECH-INTERNATIONAL EDITION (2007).

[40] Han, Xiaoqu, Nana Chen, Junjie Yan, Jiping Liu, Ming Liu, and Sotirios Karellas. "Thermodynamic analysis and life cycle assessment of supercritical pulverized coal-fired power plant integrated with No. 0 feedwater pre-heater under partial loads." Journal of cleaner production $233 \quad$ (2019): $1106-1122$. https://doi.org/10.1016/j.jclepro.2019.06.159

[41] Elghool, Ali, Firdaus Basrawi, Thamir Khalil Ibrahim, Hassan Ibrahim, M. Ishak, Mohd Hazwan bin Yusof, and Salem Abdullah Bagaber. "Multi-objective optimization to enhance the performance of thermo-electric generator combined with heat pipe-heat sink under forced convection." Energy 208 (2020): 118270. https://doi.org/10.1016/i.energy.2020.118270

[42] Zaidan, Maki Haj, Aadel Abdul Razzaq Alkumait, and Thamir Khalil Ibrahim. "Numerical Investigation of Forced Convection Flow over Backward Facing Step Affected By A Baffle Position." Journal of Advanced Research in Fluid Mechanics and Thermal Sciences 52, no. 1 (2018): 33-45.

[43] Ibrahim, Thamir K., M. M. Rahman, Obed M. Ali, Firdaus Basrawi, and Rizalman Mamat. "Optimum performance enhancing strategies of the gas turbine based on the effective temperatures." In MATEC Web of Conferences, vol. 38, p. 01002. EDP Sciences, 2016. https://doi.org/10.1051/matecconf/20163801002

[44] Ibrahim, Thamir K., and M. M. Rahman. "Optimum performance improvements of the combined cycle based on an intercooler-reheated gas turbine." Journal of Energy Resources Technology 137, no. 6 (2015). https://doi.org/10.1115/1.4030447

[45] Mohammed, Mohammed Kamil, Omar I. Awad, M. M. Rahman, G. Najafi, Firdaus Basrawi, Ahmed N. Abd Alla, and Rizalman Mamat. "The optimum performance of the combined cycle power plant: A comprehensive review." Renewable and Sustainable Energy Reviews $79 \quad$ (2017): $459-474$. https://doi.org/10.1016/j.rser.2017.05.060

[46] Awad, Omar I., R. Mamat, Thamir K. Ibrahim, Ali Thaeer Hammid, I. M. Yusri, Mohd Adnin Hamidi, Ali M. Humada, and A. F. Yusop. "Overview of the oxygenated fuels in spark ignition engine: Environmental and 
performance." Renewable and Sustainable Energy Reviews $91 \quad$ (2018): $394-408$. https://doi.org/10.1016/j.rser.2018.03.107

[47] Ibrahim, Thamir K., and M. M. Rahman. "Parametric simulation of triple-pressure reheat combined cycle: A case study." Advanced Science Letters 13, no. 1 (2012): 263-268. https://doi.org/10.1166/asl.2012.3844

[48] Ibrahim, Thamir K., and M. M. Rahman. "Parametric study of a two-shaft gas turbine cycle model of power plant." In IOP Conference Series: Materials Science and Engineering, vol. 36, no. 1, p. 012024. IOP Publishing, 2012. https://doi.org/10.1088/1757-899X/36/1/012024

[49] Zulkepli, Afzam, M. R. R. Chand, Thamir K. Ibrahim, Hamzah Sakidin, Firdaus Basrawi, and Mohd Hazwan Yusof. "Performance analysis of a Copper Indium Gallium Selenide (CIGS) based Photovoltaic Thermal (PV/T) water collector." In MATEC Web of Conferences, vol. 225, p. 04023. EDP Sciences, 2018. https://doi.org/10.1051/matecconf/201822504023

[50] Awad, Omar I., Rizalman Mamat, Thamir K. Ibrahim, Obed M. Ali, K. Kadirgama, and A. M. Leman. "Performance and combustion characteristics of an SI engine fueled with fusel oil-gasoline at different water content." Applied Thermal Engineering 123 (2017): 1374-1385. https://doi.org/10.1016/i.applthermaleng.2017.05.132

[51] Abdalla, Ahmed N., Omar I. Awad, Hai Tao, Thamir K. Ibrahim, Rizalman Mamat, and Ali Thaeer Hammid. "Performance and emissions of gasoline blended with fusel oil that a potential using as an octane enhancer." Energy Sources, Part A: Recovery, Utilization, and Environmental Effects 41, no. 8 (2019): 931-947. https://doi.org/10.1080/15567036.2018.1521889

[52] Zaidan, Maki H., Thamir K. Ibrahim, and Aadel AR Alkumait. "Performance enhancement by using wet pad in vapor compression cooling system." J Eng Technol Sci 51, no. 1 (2019): 48-63. https://doi.org/10.5614/i.eng.technol.sci.2019.51.1.4

[53] Zhao, Yongliang, Ming Liu, Chaoyang Wang, Zhu Wang, Daotong Chong, and Junjie Yan. "Exergy analysis of the regulating measures of operational flexibility in supercritical coal-fired power plants during transient processes." Applied Energy 253 (2019): 113487. https://doi.org/10.1016/i.apenergy.2019.113487

[54] Elghool, Ali, Firdaus Basrawi, Thamir Khalil Ibrahim, Khairul Habib, Hassan Ibrahim, and Daing Mohamad Nafiz Daing Idris. "A review on heat sink for thermo-electric power generation: Classifications and parameters affecting performance." Energy conversion and management $134 \quad$ (2017): $260-277$. https://doi.org/10.1016/i.enconman.2016.12.046

[55] Ibrahim, Thamir K., M. M. Rahman, M. K. Mohammed, and Firdaus Basrawi. "Statistical analysis and optimum performance of the gas turbine power plant." International Journal of Automotive and Mechanical Engineering 13 (2016): 3215. https://doi.org/10.15282/ijame.13.1.2016.8.0268

[56] Elghool, Ali, Firdaus Basrawi, Hassan Ibrahim, Thamir K. Ibrahim, Shaharin A. Sulaiman, and M. Ishak. "Study on the Performance of a Thermo-Electric Generation Model with Two Different Materials of Heat Pipe-Heat Sink." In MATEC Web of Conferences, vol. 225, p. 04009. EDP Sciences, 2018. https://doi.org/10.1051/matecconf/201822504009

[57] Basrawi, Firdaus, Izwan Ismail, Thamir Khalil Ibrahim, Daing Mohamad Nafiz Daing Idris, and Shahrani Anuar. "A study on the power generation potential of mini wind turbine in east coast of Peninsular Malaysia." In AIP Conference Proceedings, vol. 1826, no. 1, p. 020023. AIP Publishing LLC, 2017. https://doi.org/10.1063/1.4979239

[58] Basrawi, Firdaus, Thamir K. Ibrahim, Khairul Habib, Takanobu Yamada, and Daing Mohamad Nafiz Daing Idris. "Techno-economic performance of biogas-fueled micro gas turbine cogeneration systems in sewage treatment plants: Effect of prime mover generation capacity." Energy $124 \quad$ (2017): $238-248$. https://doi.org/10.1016/i.energy.2017.02.066

[59] Basrawi, Firdaus, M. R. R. Chand, K. H. Koo, and Thamir K. Ibrahim. "Theoretical analysis on the economic performance of micro gas turbine-trigeneration system with different operation strategies for residential building in a tropical region." In MATEC Web of Conferences, vol. 38, p. 01003. EDP Sciences, 2016. https://doi.org/10.1051/matecconf/20163801003

[60] Rahman, M. M., Thamir K. Ibrahim, M. Y. Taib, M. M. Noor, and Rosli A. Bakar. "Thermal analysis of open-cycle regenerator gas-turbine power-plant." Fuel 200, no. 4 (2010): 2.

[61] Ibrahim, Thamir K., Mohammed K. Mohammed, Omar I. Awad, Rizalman Mamat, and M. Kh Abdolbaqi. "Thermal and Economic Analysis of Gas Turbine Using Inlet Air Cooling System." In MATEC Web of Conferences, vol. 225, p. 01020. EDP Sciences, 2018. https://doi.org/10.1051/matecconf/201822501020

[62] Alkumait, Aadel AR, Thamir K. Ibrahim, Maki H. Zaidan, and Ahmed T. Al-Sammarraie. "Thermal and hydraulic characteristics of TiO 2/water nanofluid flow in tubes possessing internal trapezoidal and triangular rib shapes." Journal of Thermal Analysis and Calorimetry (2020): 1-14. https://doi.org/10.1007/s10973-020-10289-7

[63] Hussein, Omar A., Khairul Habib, Ali S. Muhsan, R. Saidur, Omer A. Alawi, and Thamir K. Ibrahim. "Thermal performance enhancement of a flat plate solar collector using hybrid nanofluid." Solar Energy 204 (2020): 208-222. https://doi.org/10.1016/i.solener.2020.04.034 
[64] Ibrahim, Thamir K., Firdaus Basrawi, Omar I. Awad, Ahmed N. Abdullah, G. Najafi, RizIman Mamat, and F. Y. Hagos. "Thermal performance of gas turbine power plant based on exergy analysis." Applied thermal engineering 115 (2017): 977-985. https://doi.org/10.1016/j.applthermaleng.2017.01.032

[65] Ibrahim, Thamir K., and Marwah N. Mohammed. "Thermodynamic evaluation of the performance of a combined cycle power plant." International Journal of Energy Science and Engineering 1, no. 11 (2015). 